\title{
Teaching Profession Attitudes and the Anxiety towards Mathematics Teaching of Turkish and Kosovan Teachers
}

\author{
Bünyamin Aydın (Corresponding author) \\ Dept. of Mathematics Education, Ahmet Kelesoglu Faculty of Education \\ Necmettin Erbakan University, 42090, Meram, Konya \\ Tel: 90-332-323-82-25Ｅ-mail: baydin@konya.edu.tr
}

Dilek Sezgin Memnun

Dept. of Elementary Education, Faculty of Education

Uludag University, Gorukle, Bursa, Turkey

Tel: 90-224-294-22-55 E-mail: dsmemnun@uludag.edu.tr

Received: May 24, 2018 Accepted: August 2, 2018 Published: September 11, 2018

doi:10.5296/ire.v6i2.13192 URL: http://dx.doi.org/10.5296/ire.v6i2.13192

\begin{abstract}
Kosovo needs some improvements about its education system and requires some essential and rapid changes in teachers' attitudes towards their profession and in teacher training. Attitude and anxiety are important components that affect the success in profession life and teaching of them. Because of that, the aim of this research is to examine the attitude towards teaching profession and the anxiety towards mathematics teaching, and to explore the differences between the attitude and the anxiety levels of Kosovan and Turkish teachers. The attitude towards teaching profession and the anxiety towards mathematics teaching scales were applied to a total of 64 teachers with this aim. A total of 29 of these teachers were firom Turkey while a total of 35 of them were from Kosovo. These teachers were determined randomly from the teachers working in Turkey and Kosovo. At the data analysis stage, firstly total points were divided into the items for each scale and then average points were calculated separately for each one. After that, descriptive statistics and variance analysis were applied to the average points. After the analysis of the data, it was understood that there was not a significant
\end{abstract}


difference between the anxiety towards mathematics teaching of Kosovan and Turkish teachers while there was a significant difference between their attitudes about teaching profession. Besides, it was indicated that Kosovan teachers had a higher level of attitude towards teaching profession than Turkish teachers. Additionally, there were significant relationships between the attitude towards teaching profession and the anxiety towards mathematics teaching not only for Turkish teachers but also Kosovan teachers.

Keywords: mathematics, teaching of mathematics, anxiety, anxiety towards mathematics teaching, attitude about teaching profession

\section{Introduction}

There are many factors that affect mathematics education. Anxiety towards mathematics is one of the most important problems experienced in learning mathematics and one of the most important factors that are effective in this process.

Anxiety can be described as "a state of arousal that manifests itself through physical, emotional and mental changes that one experiences when faced with at stimulus" (Aiken, 1976, cited in, Aydın and Dilmaç, 2004). Math anxiety is defined as "unreasonable anxiety that arises in situations requiring mathematics when manipulating numbers or solving a mathematical problem in daily life or academic life or similarly a state of anxiety that arises in response to any situation which involves mathematics and is perceived as threatening to self-esteem" (Deniz and Üldaş, 2008). Individuals' concerns about teaching or learning mathematics have a negative impact on learning mathematics (Cüceloğlu, 1991: 441, Rounds and Hendel, 1980: 138, cited in, S1rmac1, 2007, Berberoğlu, 2007). In other words, there is a relationship between mathematics anxiety and mathematical success (Ermest, 2000, cited in, Özdemir and Gür, 2011). Teachers with mathematics anxiety can lead to students with mathematics anxiety (Martinez, 1987: 117, cited in, Nurlu and Eti, 2016). As a result of the unfortunate events experienced in mathematics teaching, the anxiety created by the incomprehensibility of mathematics causes the negative attitude towards mathematics to develop in the first years of school. Due to the negative attitude, learning is delayed or does not occur at the desired level (Sirmac1, 2007).

Attitude can be defined as "one's preliminary thoughts formed as a result of past life and experience; it is not an observable behaviour, but a tendency that paves the way for behaviour" (Özlü, 2001). Teachers' attitudes towards the teaching profession directly affect their professional lives just as their pre-service training (Gürbüz and Kışoglu, 2007, Şimşek, 2005, Terzi and Tezci, 2007). In addition, negative teacher attitudes towards mathematics can cause students to develop negative mathematical attitudes as well (Nurlu and Eti, 2016). For this reason, it is important that teachers have positive attitudes towards mathematics teaching. To put it another way, one of the factors affecting the attitude towards mathematics is the teacher (Yenilmez and Özabac1, 2003). Development of positive attiltudes towards the teaching profession can be possible by designing professional teaching knowledge courses in such a way that they help teachers develop positive attitudes towards their profession (Aydin and Sağlam, 2012). Determining the attitudes of prospective teachers towards the teaching profession, which requires great sacrifice and continuous work, can shed light on their 
professional achievement and satisfaction. It can contribute to the development and improvement of the teaching profession (Çetin, 2006).

A review of literature has revealed studies that examine the anxiety of teachers and teacher candidates towards mathematics and learning mathematics (Yenilmez and Özabac1, 2003; Aydın, Delice, Dilmaç and Ertekin, 2009; Delice, Ertekin, Aydın and Dilmaç, 2009; Keçeci, 2011; Y1ldırım, 2013; Nurlu and Eti, 2016). As a result of the study conducted by Aydın et al. (2009) in order to explore the mathematics anxiety of primary school mathematics teachers with regard to different variables, significant differences were found in the mathematics anxiety of teacher candidates in terms of gender, class, type of high school, the university in which they received teacher education. The study conducted by Delice et al. (2009) in order to investigate the relationship between epistemological beliefs and mathematics anxiety of the students of the primary and secondary school mathematics department revealed a significant connection between these beliefs and anxiety. According to the results of a study conducted by Keçeci (2011) in order to reveal the structure and reasons of anxiety that mathematics led to in learners, anxiety-led negative attitudes towards mathematics affected development of learners' mathematical abilities, and students' fear of making mistakes in class and teachers' negative attitudes and practice during the lesson might cause math anxiety. In a study carried out by Yildırım (2013) in order to determine the level of mathematics anxiety of primary school teachers and examine this anxiety with regard to various variables, it was found that level of mathematics anxiety of the teachers was low. It was also reported that there was a significant difference between teachers' mathematics anxiety and gender variable, mathematics anxiety of teachers decreased as they grew older, mathematics anxiety of teachers increased as the service time rose, and the mathematics anxiety of graduates of primary school teacher education were lower than those of other departments. Similarly, it was also detected that teachers who loved their profession had lower levels of mathematics anxiety than those who did not.

The results of the study conducted by Nurlu and Eti (2016) in order to determine the mathematics anxiety levels of primary education teacher candidates, and examine their views on mathematics anxiety indicated that the average anxiety levels of a significant part of the primary education teacher candidates varied from "I am never anxious" and "I am slightly anxious". Moreover, the sources of mathematics anxiety of the teacher candidates were explained as teacher-family attitudes, inadequate mathematics study, questioning mathematical knowledge, lack of confidence and the place of mathematics in the education system.

There are also various studies that examine the attitudes of the teachers and teacher candidates towards mathematics (Kaplan and İpek, 2002; Terzi and Tezci, 2007; Çapri and Çelikkaleli, 2008, Bulut, 2009, Tekerek and Polat, 2011, Aydın and Sağlam, 2012, Taşdemir, 2014). As a result of the study carried out by Kaplan and İpek (2002) in order to examine the attitudes of candidates of mathematics teaching towards the teaching profession, it was observed that the attitudes of the candidates of mathematics teaching towars the teaching profession did not differ according to sex but according to the classes and faculties (education-science). In the study by Terzi and Tezci (2007) which aimed to investigate the 
attitudes of the education faculty students towards the teaching profession, it was understood that the attitudes of the students towards the profession were positive, at the level of "I agree" and above. It was indicated that the attitude scores of female students were higher than those of male students, and the attitude scores of the students studying in social and linguistic fields were higher than those of the students studying in the fields of science and mathematics. It was also reported that there was no significant difference in student attitudes in terms of program and class variables. In the study carried out by Çapri and Çelikkaleli (2008) in order to examine teacher candidates' attitudes towards the teaching profession and their professional competence beliefs with regard to gender, program and faculties, it was stated that gender had a significant effect on the attitudes of teacher candidates towards the teaching profession and that program and faculty variables had no meaningful impact. According to the results of the study conducted by Bulut (2009) in order to evaluate the attitudes of teacher candidates towards the teaching profession, the attitudes of the prospective teachers towards the teaching profession did not cause a significant difference with regard to university and gender variables.

It was also stated that the attitudes of the prospective teachers towards the teaching profession were at the level of "agree". The results of the study carried out by Tekerek and Polat (2011) in order to determine the level of the attitudes of prospective teachers towards the teaching profession indicated that the students who voluntarily chose the department in which they were studying held more positive attitudes towards the profession than the ones who did not choose their department voluntarily.

In a similar way, it is stated that the students who want to be a teacher after graduation are more positive than those who do not want to be a teacher when they graduate. Moreover, the attitudes towards the teaching profession vary according to the university the students study at. As a result of the study Aydın and Sağlam (2012) carried out in order to find out the attitudes of preservice teachers towards teaching, it was found out that the attitudes of the last year students towards the teaching profession change according to gender, the reason why they chose the department they are studying at, and their mothers' level of education. Taşdemir (2014) carried out a study on the analysis of the primary school mathematics teacher candidates' attitudes towards the teaching profession concerning different variables. The results of the study show that the attitudes of the students towards the teaching profession do not have a significant difference according to gender, grade level, the education levels of the mothers and fathers, and the high school the students graduated from. It is also explained that the students' attitudes towards the teaching profession is positive.

Very few studies (Yenilmez and Özabac1, 2003; S1rmac1, 2007) dealt with both the attitudes and anxiety of the teachers or teacher candidates towards mathematics. Yenilmez and Özabac1 (2003) carried out their study in order to find out the teaching school students' attitudes and anxieties towards mathematics and the variables related to these factors. As a result of this study, it was reported that there is a strong relationship between the attitudes towards mathematics and mathematics anxiety. As a result of the study carried out by Sirmaci (2007) in order to find out the university students' attitudes and anxieties towards mathematics, it was found out that there was not a significant difference between male and female students 
concerning mathematics anxiety, however, mathematics anxiety differed according to the department, grade, and the most and least enjoyed lessons. It is also revealed that the attitudes of male and female students towards the perception of the necessity of mathematics, the perceived parent attitudes on mathematics, and seeing mathematics as a male profession create a difference on behalf of the females. Furthermore, it is stated that attitudes towards mathematics meaningfully differ according to the departments, grades, the most and the least enjoyed lessons. In addition, it is reported that the high school the participants graduated from and their fathers' jobs do not differ in a statistically meaningful way.

Since very few studies dealing with both teachers' or teacher candidlates' attitudes and anxieties together have been reached, the present study covers the teachers' anxiety towards teaching mathematics and their attitudes towards the mathematics teaching profession at the same time. In addition, different from abovementioned researches, the present study was carried out with the teachers from Kosovo and Turkey. Therefore, teachers from different cultures were compared. The reasons behind including the teachers from Kosovo into the present research were that the teaching experience and reflective teaching methods are carried out without any systematic perspective or a clear aim and objectives, that the teacher education program in Kosovo has recently been reviewed, and that, within this concern, new teacher education schools have been established (Pupovci, Hyseni and Salıhaj, 2001; Y1ldırım and Y1ldirım, 2012). As a result, the present study aims to investigate the teachers working in Kosovo and Turkey in terms of their attitudes towards the profession and their anxiety levels on teaching mathematics; and following this, to look into the relationship and the differences between the teachers' attitudes and anxieties in Kosovo and Turkey. For this purpose, the research problems given below were tried to be answered:

1. What is the mathematics teaching anxiety level of the teachers working in Kosovo and Turkey?

2. Is there a significant difference between the anxiety levels of the teachers working in Kosovo and in Turkey for teaching Mathematics?

3. What are the attitudes of the teachers who work in Kosovo and in Turkey towards the mathematics profession?

4. Is there a significant difference between the attitudes of teachers working in Kosovo and in Turkey towards mathematics profession?

5. Is there a meaningful relationship between the mathematics teaching anxieties of the teachers working in Kosovo and their attitudes towards the profession of teaching mathematics?

6. Is there a meaningful relationship between the mathematics teaching anxieties of the teachers working in Turkey and their attitudes towards the profession of teaching mathematics?

The present study is different from the previous studies since it investigates the mathematics teaching anxieties of the teachers in Kosovo and Turkey, and since it will focus on the comparisons of these attitudes and anxieties between the two countries. 


\section{Methodology}

In this section, the participant teachers who are working in Kosovo and Turkey, anxiety of teaching mathematics and attitudes towards mathematics profession scales that were answered by the participant teachers, information about data collection, and the analysis that was carried out to find out the similarities and differences between the anxieties and the attitudes of the teachers are explained.

\subsection{Research Model}

The present study was carried out by applying the relational screening model which is a quantitative method. As it is known, the screening models are the approaches that aim to find out a situation in the past or at present, as it is (Karasar, 2003).

\subsection{Participants}

The 64 teachers participated in the present study. The 29 of these teachers work in Turkey and 35 of them work in Kosovo. In order to decide on the teachers to participate in the study random sampling method, one of the probability sampling methods, was used. In random sampling method, the sample is selected randomly (Yıldırım and Şimşek, 2005: 104). The researchers were especially careful about choosing the teachers that were eager to take part in the study.

\subsection{Data Collection and Data Collection Tools}

Anxiety of Mathematics Teaching Scale which was developed by Peker (2006) and Attitudes Towards Mathematics Profession Scale which was developed by Aşkar and Erden (1987) were delivered to the teachers from Kosovo and Turkey in the 2015-2016 fall term.

Anxiety of Mathematics Teaching Scale is a five point likert and three dimensional scale that consists of 23 items. The Cronbach Alpha reliability of the scale is 0.90 , as stated by Peker (2006). Therefore, it can be said that the Turkish version of the scale is reliable. The least score that can be gained from the scale is 23 and the highest one is 115 . The Cronbach Alpha reliability results gained from the present study is .97. Attitudes Towards Mathematics Profession Scale is a five point likert and one dimensional scale that consists of 10 items. Six of these items are positive and four of them are negative. The least score that can be obtained from the scale is 10 and the highest one is 50 . The Cronbach Alpha reliability results gained from the present study for this scale is .85 . Therefore, it can be said that the data is suitable and reliable for the present study. The items in both scales are graded as "I strongly agree", "I agree", "I am undecided", "I disagree", and "I strongly disagree".

\subsection{Data Analysis}

For the analysis of data gathered in the present study, the items in the scales were transferred to the computer by grading the items from 1 to five in a way that "I strongly agree corresponds to 5 while "I strongly disagree" corresponds to 1 . Positive items on the attitude scale and positive items on the anxiety scale (as negative materials would show high concern) were scored in reverse order. Then, the total scores the teachers received from each scale 
were calculated for the research data, and the average scores of each teacher from two different scales were calculated separately by dividing these total scores by the number of items in these scales.

In order to interpret the average scores, the intra-group score range was calculated. In this context, the group interval coefficient value was determined as "the difference between the largest value and the smallest value in the sequence of measurement results divided by the number of groups determined (Kan, 2009: 407)". Accordingly, in the interpretation of the answers given by participant teachers to their anxiety and attitude scales, the evaluation interval was calculated as approximately (5-1) $/ 5=0.8$. Similarly, intervals for interpreting teachers' responses to the scale; " 4.21-5.00 I strongly agree, 3.41-4.20 I agree, 2.61-3.40 I am undecided, 1.81-2.60 I disagree, and 1.00-1.80 I strongly disagree ".

In the analysis of the data received, the Kolmogorov-Smirnov test was used to test the normality assumption of the mean of the scores obtained from the attitude and anxiety scales included in the research, and the Levene statistic was used to test the homogeneity of the average scores. As a result of the analysis, it was understood that the variance of the data for the maths teaching anxiety and attitude scales for the mathematics profession, that is; the variance of the teacher score averages, were homogeneous $(\mathrm{FK}=0.020$ and $\mathrm{FT}=0.589 ; \mathrm{pK}$ $=.889$ and $\mathrm{pT}=.446$, respectively). As a result of analyses carried out regarding whether the data were normally distributed, for the anxiety scale for maths teaching, the significance value for the calculated test result of the data obtained from Kosovan teachers was pk $=.000$ whilst the significance value for the calculated test result of the data obtained from Turkish teachers were found to be $\mathrm{pt}=.122$. This indicates that the data obtained from Kosovan teachers do not show normal distribution, yet the data received from Turkish teachers show normal distribution. For the attitude scale for attitude scales for the mathematics profession, the significance value for the calculated test result of the data obtained from Kosovan teachers was $\mathrm{pk}=.000$ whilst the significance value for the calculated test result of the data obtained from Turkish teachers were found to be $\mathrm{pt}=.111$. This points out that the data received from Turkish teachers were normally distributed, however again; the data obtained from Kosovo did not have normal distribution. Therefore, for comparative analysis of data concerning teachers in Turkey the use of parametric analyses was preferred while for the statistical analysis of comparative data of teachers in Kosovo and in Turkey, the use of non-parametric was found to be suitable.

Analysis of the data was carried out via SPSS 23.0. In this section; Mann Whitney U Test and Spearman correlation analysis from nonparametric analyzes besides descriptive and correlational analyzes were used in the analysis of the data in the research. In addition, in the analysis of the obtained research data, the significance levels of 0.05 and 0.01 were taken as reference.

\section{Findings and Discussion}

Statistical analyses carried out to identify the anxiety of maths teaching and the attitudes towards mathematics profession of the teachers who participated in the study in Kosovo and Turkey, and to investigate the differences of these attitudes and anxieties were included in 
this part. In this context, firstly the descriptive analyses were carried out for the anxiety of math teaching of the teachers in Kosovo and Turkey. At this stage, frequency and percent values obtained from the scores calculated for each teacher were shown in Table 1 below.

Table 1. Calculated percent and frequency values for the anxiety of math teaching of the teachers working in Kosovo and Turkey

\begin{tabular}{lcccccccccc}
\hline \multicolumn{6}{c}{ Average Score Distribution of Anxiety Scale for Teaching Mathematics } \\
\hline & \multicolumn{1}{c}{ between } & between & between & between & \multicolumn{2}{l}{ between } \\
& $4.21-5.00$ & $3.41-4.20$ & $2.61-3.40$ & $1.81-2.60$ & $1.00-1.81$ \\
\cline { 2 - 11 } Teachers & $\mathrm{f}$ & $\%$ & $\mathrm{f}$ & $\%$ & $\mathrm{f}$ & $\%$ & $\mathrm{f}$ & $\%$ & $\mathrm{f}$ & $\%$ \\
\hline Kosovo & 0 & 0.0 & 2 & 5.7 & 2 & 5.7 & 16 & 45.7 & 15 & 42.9 \\
Turkey & 0 & 0.0 & 1 & 3.5 & 5 & 17.2 & 13 & 44.8 & 10 & 34.5 \\
\hline
\end{tabular}

As can be seen from the table above, a very small proportion of teachers in Kosovo and in Turkey who participated in this study got scores corresponding to "definitely agree" (respectively 5.7\% and 3.5\%) from the scale, which indicates this limited number of teachers have high anxiety regarding teaching Maths. It is understood that a great majority of teachers who work in Turkey and in Kosovo; however, got scores corresponding to "disagree" and "totally disagree" (respectively $88.6 \%$ and $79.3 \%$ ) from the scale. This points out that a large proportion of these teachers have quite low anxiety regarding the anxiety for teaching Maths. Then, Mann-Whitney $U$ test, which is nonparametric equivalent of independent samples t-test was performed to reveal whether there is significant difference in the level of anxiety of those teachers who work in Turkey and Kosovo. In this step, the answer for the research question, "Is there a significant difference between the anxiety levels of teachers working in Kosovo and in Turkey for teaching Maths?" was sought. The results obtained are given in the following table.

Table 2. Mann-Whitney $U$ test results regarding the anxiety levels of the teachers in Turkey and Kosovo for teaching Maths

\begin{tabular}{llccrcc}
\hline & Teachers & $\mathrm{n}$ & Mean Rank & Rank sum & U & $\mathrm{p}$ \\
\hline \multirow{2}{*}{ Anxiety } & Kosovo & 35 & 29.3 & 1024.5 & 394.5 & .127 \\
& Turkey & 29 & 36.4 & 1055.5 & & \\
\hline
\end{tabular}

In the analysis, it is found out that there is not a significant difference between the anxiety scores of the teachers surveyed in Kosovo and the teachers in Turkey for teaching math $(\mathrm{U}=$ $394.5, \mathrm{p}=127)$.

Secondly, the answer to the third research question, "What are the attitudes of teachers who 
work in Kosovo and in Turkey towards the mathematics profession?", was sought within the scope of research. In this context, the frequency and percent values regarding this information of teachers are given in Table 3 below.

Table 3. Calculated percent and frequency values for teachers' attitudes regarding the profession

\begin{tabular}{llllllllllll}
\hline \multicolumn{1}{c}{ Average Score Distribution of Attitude Scale Regarding Maths Profession } \\
\hline & \multicolumn{1}{c}{ between } & between & between & between & \multicolumn{2}{l}{ between } \\
& $4.21-5.00$ & $3.41-4.20$ & $2.61-3.40$ & $1.81-2.60$ & $1.00-1.81$ \\
\cline { 2 - 11 } Teachers & $\mathrm{f}$ & $\%$ & $\mathrm{f}$ & $\%$ & $\mathrm{f}$ & $\%$ & $\mathrm{f}$ & $\%$ & $\mathrm{f}$ & $\%$ \\
\hline Kosovo & 24 & 68.6 & 10 & 28.6 & 0 & 0.0 & 0 & 0.0 & 1 & 2.8 \\
Turkey & 18 & 62.1 & 11 & 37.9 & 0 & 0.0 & 0 & 0.0 & 0 & 0.0 \\
\hline
\end{tabular}

As can be seen from the table above, a significant number of teachers who participated in this research from Kosovo and Turkey $(68.6 \%$ and $62.1 \%$, respectively) received scores corresponding to "strongly agree" from the scale. This indicates that teachers' attitudes towards the mathematics profession are quite high. However, these obtained percentages indicate that teachers working in Kosovo have a higher level of positive attitude. When the participant teachers' attitude scores corresponding to "strongly agree" and "agree" were examined, the majority of teachers participating in the study from Kosovo and from Turkey (respectively $97.2 \%$ and $100.0 \%$ ) was found out to have a positive attitudle. Then, an answer to the fourth research problem, "Is there a significant difference between the attitudes of teachers working in Kosovo and in Turkey towards mathematics profession?" was sought. At this stage, Mann-Whitney U test, which is nonparametric equivalent of independent samples t-test, was performed to investigate whether there are significant differences in these attitudes of those teachers in Turkey and in Kosovo. The results obtained are also shown in the following table.

Table 4. Mann Whitney U test results related to teachers' attitudes towards mathematics profession in Turkey and Kosovo

\begin{tabular}{llccccc}
\hline & Teachers & $\mathrm{n}$ & Mean Rank & Rank Sum & $\mathrm{U}$ & $\mathrm{p}$ \\
\hline \multirow{2}{*}{ Attitude } & Kosovo & 35 & 36.9 & 1290.5 & 354.5 & .04 \\
& Turkey & 29 & 27.2 & 789.5 & & \\
\hline
\end{tabular}

As can be seen in the analysis conducted, there is a significant differece between the teachers' scores of attitudes towards math profession in Kosovo and the math attitude scores of teachers in Turkey $(U=354.5 ; p=.04)$. In addition, when the results of descriptive analysis are taken into consideration, it is understood that the teachers working in Kosovo have a higher 
level of positive attitude. Finally, answers were tried to be found to the 5th and the 6th questions specifically " Is there a significant relationship between the anxiety levels of the teachers working in Kosovo for teaching Maths and their attitudes towards maths profession?" and "Is there a significant relationship between the anxiety levels of the teachers working in Turkey for teaching Maths and their attitudes towards maths profession?". At this stage, firstly Spearman Correlation Analysis, one of the non-parametric analysis tests, was performed to find out the attitude scores of teachers working in Kosovo towards the maths profession and their anxiety scores for mathematics teaching, and the results of the analysis are given in the following table.

Table 5. Correlation analysis results of profession attitude scores of the teachers in Kosovo and their anxiety scores for teaching

\begin{tabular}{lc}
\hline & Attitude towards Mathematics Profession \\
\hline Anxiety of Teaching Mathematics & $.327^{*}$ \\
\hline${ }^{*} \mathrm{p}<01$ &
\end{tabular}

According to the analysis result on the table given above, a low level of significant correlation was found between the anxiety scores of the teachers participating in the research and working in Kosovo related to teaching mathematics and their attitude scores towards mathematics profession.

Secondly, for the attitude scores of the teachers working in Turkey related to Mathematics profession and their anxiety scores for teaching mathematics, due to the homogeneity of the variance regarding these data and the normal distribution, Pearson correlation analysis, a parametric analysis method, was conducted and analysis results were presented in the Table below.

Table 6. Correlation analysis results of profession attitude scores of the teachers in Turkey and their anxiety scores for teaching

\begin{tabular}{lc}
\hline & Attitude towards Mathematics Profession \\
\hline Anxiety of Teaching Mathematics & $.504 *$ \\
\hline${ }^{*}<<.01$ &
\end{tabular}

The analysis result on the table given above indicates that a medium level of significant correlation was found between the anxiety scores of the teachers participating in the research and working in Turkey related to teaching mathematics and their attitude scores towards mathematics profession. 


\section{Conclusion ve Implications}

In this study, levels of anxiety towards teaching maths and attitudes towards mathematics profession of the teachers working in Turkey and Kosovo were examined comparatively.

As a results of the investigations, it was found that a vast majority of the teachers working in Kosovo and Turkey have low level of anxiety towards maths teaching and almost all of them have positive attitudes towards mathematics profession. This finding related to attitude was supported with the study by Terzi and Tezci (2007) in which attitudes of students at education faculty towards teaching profession was scored as "agree" and over; with the study by Bulut (2009) in which the obtained attitudes towards teaching profession was in the level of "agree" and with the study of Taşdemir (2014) in which the attitudes of the students towards teaching profession was positive.

The finding obtained in the scope of this research related to mathematics anxiety shows similarity with the results of the study by Yildirim (2013) that reveals that the teachers have low level of maths anxiety; with the results of the study by Nurlu and Eti (2016) in which the mean anxiety level of a considerable number of the preservice teachers of primary education is between the levels "I am never anxious" and "I feel slightly anxious".

As a result of the statistical analyses conducted for the data of this study, no significant difference was found between anxiety levels of the teachers in Turkey and Kosovo for teaching maths. This finding differs from the result of the study conducted by Aydin et al. in which significant differences were found in the preservice teachers' anxiety levels towards maths depending on the the institution where they were educated. Besides, this result points to the fact that the anxiety levels of the teachers in Turkey and Kosovo, who participated in the study, towards teaching maths are similar.

In addition to this, significant differences were found between the attitudes of the teachers in Turkey and the attitudes of the teachers in Kosovo towards maths teaching. Also, according to the results of descriptive analysis, it was revealed that compared to the teachers working in Turkey, the teachers working in Kosovo have higher levels of positive attitudes. This situation may arise from the positive effect of the changing education and teacher training system in Kosovo on the attitudes of teachers towards the profession (Y1ldirım ve Yildirım, 2012). Because with the aim of training teachers who can use the new methods and techniques in Kosovo, who can decide for which lessons these methods and techniques are more suitable and who can put these into action, who can follow and investigate the changes and developments, new education faculties are being opened (Pupovci, Hyseni ve Salihaj, 2001). The finding acquired in the scope of this study which indicates that compared to the teachers working in Turkey, the teachers working in Kosovo have higher levels of positive attitudes do not overlap with the result of the study conducted by Bulut (2009) that reveals the attitudes of preservice teachers towards teaching profession doesn't create a significant difference in terms of the variable "university". On the other hand, this result is similar to the result of the study carried out by Tekerek and Polat (2011), which demonstrates that attitudes towards teaching profession change depending on the university where the students were educated. 
As a result of the correlation analysis in which significant relationships between the attitudes of teachers working either in Turkey or in Kosovo towards the profession and their levels of anxiety towards maths teaching were investigated, a low level of significant relationship was found between the anxiety scores of the teachers working in Kosovo towards maths teaching and their scores of attitude towards mathematics profession. Thus, this situation points to the fact that the anxiety of the teachers who work in Kosovo and participated in this study towards teaching maths affected their attitudes towards maths profession, even a little; or that their attitudes affected their level of anxiety towards maths teaching, although very little. Moreover, a moderate level of significant relationship was found between the anxiety scores of the teachers working in Turkey towards maths teaching and their scores of attitude towards maths profession. This situation, on the other hand, displays that the anxiety of the teachers working in Turkey and participating in the study towards teaching maths affects their attitudes towards maths profession or their attitudes towards maths teaching affects their anxiety towards teaching maths. This finding showed similarity with the result of the study by Yenilmez and Özabac1 (2003) which presented that there is a high relationship between the attitudes of teaching school students towards maths and their anxiety levels.

In the studies to be conducted, different teaching knowledge, skills, beliefs and attitudes of teachers working in Kosovo and Turkey can be compared. Furthermore, in these studies to be carried out, some more detailed results can be added and presented.

\section{References}

Aşkar, P. ve Erden, M. (1987) Öğretmenlik mesleğine yönelik tutum ölçeği. Çă̆daş Ĕ̆itim, 121(12), 8-11.

Aydın, E. ve Dilmaç, B. (2004). Matematik Kaygısı. Eğitime ilişkin Çeşitlemeler.(Ed. M. Gürsel). Konya: Eğitim Kitabevi.

Aydın, E., Delice, A., Dilmaç, B. ve Ertekin,E. (2009). İlköğretim matematik öğretmen adaylarının matematik kaygı düzeylerine cinsiyet, sınıf ve kurumdeğişkenlerinin etkisi. İlkögretim Online, 8(1), 231-242.

Aydın, R. ve Sağlam, G. (2012). Öğretmen adaylarının öğretmenlik mesleğine yönelik tutumlarının belirlenmesi. Türk Ĕ̈itim Bilimleri Dergisi, 10(2), 257-294.

Berberoğlu, G. (2007). Türk bakış açısından PISA araştırma sonuçları. 17.05.2011 tarihinde http://www.konrad.org.tr/Egitimturk/07girayberberoglu.pdf adresinden eldeedilmiştir.

Bulut, İ. (2009). Öğretmen adaylarının öğretmenlik mesleğine ilişkin tutumlarının değerlendirilmesi (Dicle ve Fırat Üniversitesi örneği). Dicle Üniversitesi Ziya Gökalp Ĕ̆itim Fakültesi Dergisi, 14, 13-24.

Çapri, B. ve Çelikkaleli, Ö. (2008). Öğretmen adaylarının öğretmenliğe ilişkin tutum ve mesleki yeterlik inançlarının cinsiyet, program ve fakültelerine göre incelenmesi. İnönü Üniversitesi Ĕ̈itim Fakültesi Dergisi, 9(15), 33-53.

Delice, A., Ertekin, E., Aydın, E. ve Dilmaç, B. (2009). Öğretmen adaylarının matematik kaygısı ile bilgibilimsel inançları arasındaki ilişkinin incelenmesi. Uluslararası İnsan 
Bilimleri Dergisi, 6(1), 361-375.

Deniz, L. ve Üldaş, İ. (2008). Öğretmen ve öğretmen adaylarına yönelik matematik kayg1 ölçeğinin geçerlilik ve güvenilirlik çalışması. Eurasian Journal of Educational Research, 30, 49-62

Gürbüz, H. ve Kışoğlu, M. (2007). Tezsiz yüksek lisans programına devam eden fen-edebiyat ve eğitim fakültesi öğrencilerinin öğretmenlik mesleğine yönelik tutumları (Atatürk Üniversitesi örneği). Erzincan Eğitim Fakültesi Dergisi, 9 (2), 71-83.

Kaplan, A. ve İpek, A.S. (2002). Matematik öğretmenliği adaylarının öğretmenlik mesleğine yönelik tutumlarının incelenmesi. Eğitim ve Bilim, 125, 69-73.

Nurlu, Ö. ve Eti, İ. (2016). Temel eğitim öğretmen adaylarının matematik kaygı düzeylerinin belirlenmesi ve kaygı kaynaklarına ilişkin görüşlerinin incelenmesi. Eurasian Education \& Literature Journal, 4, 28-37.

Özdemir, E. ve Gür, H. (2011). Matematikkaygısı-endişesi ölçeğiin geçerlik ve güvenilirlik çalışması. Eğitim ve Bilim, 36(161), 39-50.

Özlü, Ö. (2001). Ortaöğretim öğrencilerinin matematiğe karşı tutumları (Yayımlanmamış yüksek lisans tezi). Marmara Üniversitesi, İstanbul.

Peker, M. (2006). Matematik öğretmeye yönelik kayg1 ölçeğinin geliştirilmesi. Journal of Educational Sciences \& Practices, 5(9), 73-92.

Pupovci, D., Hyseni, H., \& Salıhaj, J. (2001). Arsimi Në Kosov ë. Priştine:ë Druck Art Yayın1.

Sırmacı, N. (2007). Üniversite öğrencilerinin matematiğe karşı kaygı ve tutumlarının incelenmesi. Erzurum örneklemi. Eğitimve Bilim, 32(145), 53-70.

Şimşek, H. (2005). Ortaöğretim Alan Öğretmenliği Tezsiz Yüksek Programına Devam eden Öğrencilerin Öğretmenlik Mesleğine Yönelik Tutumları. Yüzüncü Yıl Üniversitesi, Elektronik Eğitim Fakültesi Dergisi, 2(1).

Taşdemir, C. (2014). İlköğretim matematik öğretmen adaylarının öğretmenlik mesleğine yönelik tutumlarının incelenmesi. Bilgisayar ve Ĕ̆gitim Araştırmaları Dergisi, 2(3), 91-114.

Tekerek, M. ve Polat, S. (2011). Öğretmen adaylarının öğretmenlik mesleğine ilişkin tutumlar1. 5th International Computer \& Instructional Technologies Symposium, 22-24 September, Firat Ünversitesi, Elazığg, Türkiye.

Terzi, A.R. ve Tezci, E. (2007). Necatibey Eğitim Fakültesi öğrencilerinin öğretmenlik mesleğine ilişkin tutumları. Kuram ve Uygulamada Ĕ̆itim Yönetimi, 52, 593-614.

Yenilmez, K. ve Özabacı, N.Ş. (2003). Yatılı öğretmen okulu öğrencilerinin matematik ile ilgili tutumları ve matematik kaygı düzeyleri ar.asındaki ilişki üzerine bir araştırma. Pamukkale Üniversitesi Ĕ̌itim Fakültesi Dergisi, 14(2), 132-146.

Yıldırım, K. (2013). Sınıf öğretmenlerinin matematik kaygı düzeylerinin incelenmesi 


\section{Macrothink}

(Yayımlanmamış Yüksek Lisans Tezi). Adıyaman Üniversitesi, Adıyaman.

Yıldırım, B. ve Yıldırım, S. (2012). Kosova'da öğretmen yetiştirme politikası (1990-2010). e-Journal of New World Sciences Academy, 7(4), 1054-1062.

\section{Copyright Disclaimer}

Copyright reserved by the authors.

This article is an open-access article distributed under the terms and conditions of the Creative Commons Attribution license (http://creativecommons.org/licenses/by/3.0/). 